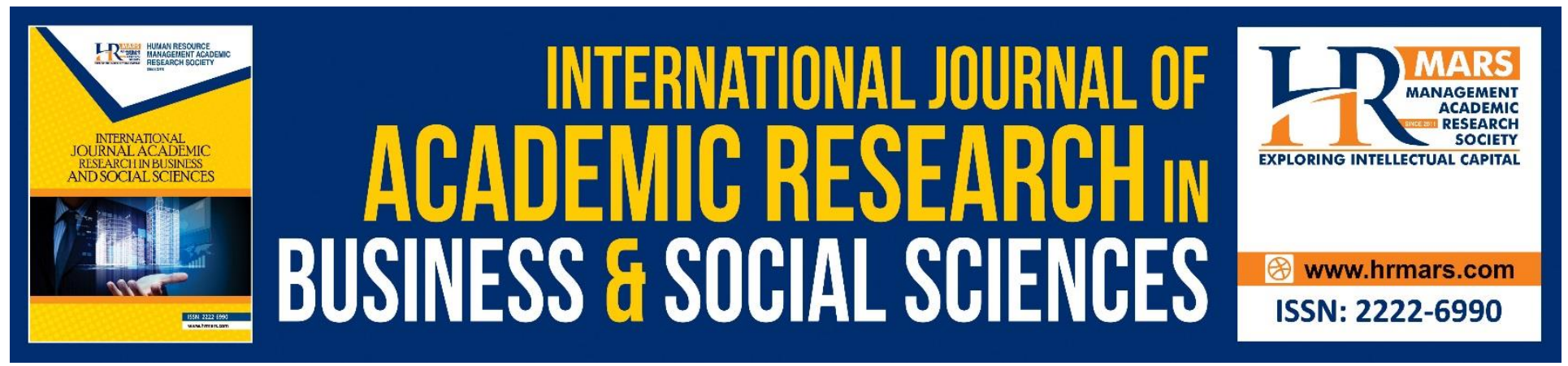

\title{
Effect of Human Resource Management Practices on Employees Satisfaction: An Empirical Study of Iraq
}

Azhar Naima M.

To Link this Article: http://dx.doi.org/10.6007/IJARBSS/v9-i2/5547

DOI: $\quad 10.6007 /$ IJARBSS/v9-i2/5547

Received: 02 Jan 2019, Revised: 23 Feb 2019, Accepted: 01 March 2019

Published Online: 02 March 2019

In-Text Citation: (Azhar, 2019)

To Cite this Article: Azhar, N. M. (2019). Effect of Human Resource Management Practices on Employees Satisfaction: An Empirical Study of Iraq. International Journal of Academic Research in Business and Socal Sciences, 9(2), 322-334.

Copyright: (C) 2019 The Author(s)

Published by Human Resource Management Academic Research Society (www.hrmars.com) This article is published under the Creative Commons Attribution (CC BY 4.0) license. Anyone may reproduce, distribute, translate and create derivative works of this article (for both commercial and non-commercial purposes), subject to full attribution to the original publication and authors. The full terms of this license may be seen at: $\underline{\text { http://creativecommons.org/licences/by/4.0/legalcode }}$

Vol. 9, No. 2, 2019, Pg. 322 - 334

Full Terms \& Conditions of access and use can be found at http://hrmars.com/index.php/pages/detail/publication-ethics 


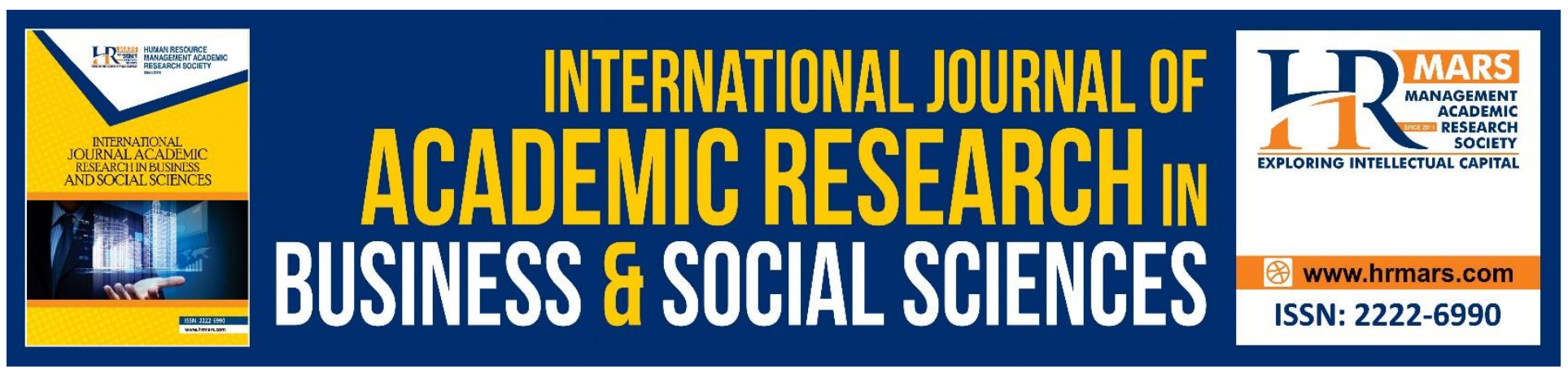

\title{
Effect of Human Resource Management Practices on Employees Satisfaction: An Empirical Study of Iraq
}

\author{
Azhar Naima M. \\ College of business economics, Nahrain University, Iraq \\ Email: azhar.naima.m@gmail.com
}

\begin{abstract}
The purpose of the study is to analyze the human resource management practices effects the employee satisfaction. Human resource management involves in providing the services to facilitate working culture and develop satisfaction among the employees. It is suggested that organization profitability and growth in the market is directly associated with the human resource management efficiency and effectiveness in the organization. A sample of 380 respondents was used to analyze the data. To analyze the data SPSS was used. The data analysis included demographic analysis, descriptive statistics, correlation and regression analysis. The result showed that of planning and recruitment, training, compensation and performance appraisal have significant impact on employee satisfaction. The discussion of the result is presented and the limitation and future avenue of the research were discussed.
\end{abstract}

Keywords: Human Resource Practices, Employee Satisfaction, Iraq

\section{Introduction}

In the current world; business has been emerged towards the competitive market that has urged the urgency to develop those practices that increases the efficiency and effectiveness of the individuals considerably therefore; the human resource management practices are highly concerned and become effective to be focused. In order to analyze the human resource management practices there is been the concern over the employee development, recruitment, motivation, job satisfaction and attainment of goals accordingly (Watson, 2010). The human resource management has been extended from the point where only personnel managers were looking the matters of recruitment, payroll, filling the vacant positions, promotions and other individual issues. Human resource management is being considered as the organizational department that is concerned to recruit capable employees, provide them training and develop for the future to lead the organization (Wood and Wall, 2002).

In the current environment; human resource management has emerged as a main component of the organization that becomes the strategic partner for the stakeholders and involve in the development 
of strategic goals for the organization (Darwish, 2013). The human resource management has brought the attention of the market towards competing through the talent management and capabilities of the individual to gain the competitive advantage while in the past employees were not considered as the asset for the organization but the phenomenon has been changed and employees are the main force that enable the organization to gain the competitive edge over others (Darwish, 2013). In the last two decades top management has changed the perception about the employees that they are the competitive strength for the organization that supporting services are the helping hands for them to produce efficiency and performance for the organizational success and meeting the strategic objectives (Shaukat et al, 2015).

According to Dessler, (2013) suggested that human resource management is based upon the policies and procedures to carry out the operations of the department which includes the recruitment, selection, compensation, training and development, public relations and others. On the basis of this it is required from the organizational perspective that employee capabilities, skills collectively considered as the human capital which enable the organization to gain and sustain their competitive advantage over others (Shaukat et al, 2015). Therefore; the requirement of the making the organization strong human resource management policies and procedures should be implemented and focus should be upon the employee they should follow the instructions accordingly. Performance of the employee is directly linked with the employee satisfaction (Haquec et al, 2013). For any organization the key component is the human capital of that organization. Even in today's contemporary business environment still organizations are facing issues regarding the human resources which are one of the main factors for the organizational performance ultimately leading to the development and growth of the organization. It is indispensable for the organizations to articulate such HR policies which are effective in gaining the satisfaction of the employees towards their jobs and ultimately leading to better organizational performance. The same is true for the Iraqi organizations. Hence the purpose of the study is to analyze the impact human resource practices on employees' satisfaction in Iraq. Human resource management involves in providing the services to facilitate working culture and develop satisfaction among the employees (Shadare et al, 2009). It is suggested that organization profitability and growth in the market is directly associated with the human resource management efficiency and effectiveness in the organization.

\section{Research Questions}

1. Is there any impact of planning and recruitment on employee satisfaction?

2. Is there any role of training in employee satisfaction?

3. It there any relationship between the compensation and employee satisfaction?

4. Is performance appraisal related to employee satisfaction?

\section{Research Objectives:}

To understand the relationship of planning \& recruitment with employee satisfaction.

To examine the impact of training on employee satisfaction.

To assess the relationship between compensation and employee satisfaction.

To find out the effect of performance appraisal and employee satisfaction. 


\section{Literature Review}

Planning of human resource is directly associated with the organizational strategies and effectiveness of the human resource management practices in the organization. The human resource strategic planning is associated with the recruitment, training and retaining the employees of the organization (Al Saleem, 2010). Planning of human resource department is associated with the strategic planning of the organization to recruit right person for the right job, provide training and evaluate performance of the individuals in order to motivate them and urge them to produce quality results for the organization. It is required to collect the concrete and purposeful information that enable the organization to take effective strategic decision which enable the organizational success (Joudeh, 2010). Recruitment is defined as the system to hire the individuals for the selected job and it depends upon the individual they have different perspective and perception to join the organization such as, market reputation, culture, compensation packages, bonus and others benefits (Umphress et al, 2007).

Recruitment and selection is considered as the process which involves two ways that suggest individual select the organization to apply for the said position and organization is making the decision to select the individual. The main feature of this process is to get the right employee to the right place in the organization. Recruitment and selection is a time taking process which also include some investment in the individual as well (Fening and Amaria, 2011). Recruitment is being defined as the activities of the organization where a pool of different individuals are being created that have shown their interest in the required position of the organization (Bratton and Gold, 2012). In other means it provides the information regarding the individual's capabilities and individuals are being informed about the organizational benefits and perks (Heneman and Milanowski, 2007). Human resource planning is being defined as the system that is associated with the human resource requirement of the organization in order to focus upon the strategic plans and meet the future requirement of capable individuals. Human resource planning is the main stream that increases the feasibility to increase the competitive advantage and decreases the employee turnover considerably to facilitate organizational profitability. The purpose of this exercise to increase the succession planning that produces the employees to back the different positions in the organization in order to meet the organizational objectives (Bhagul, 2014).

Compensation includes variable pay, incentives and one of the most satisfying element for the employee to increase productivity (Curran and Walsworth, 2014; Green and Heywood, 2008; Pendleton et al, 2009). In the current environment or market compensation is the important aspect of gaining the competitive advantage. There are different types of compensation involves in the market such as: performance based, profit based, incentive based, ownership based to retain and sustain the employees considerably (Heywood and Wei, 2006); employees get satisfied and develop the trust of the employees in the organization (Moriones et al, 2009). The compensation packages enable the employees to produce quality results for the organization and enable them to get satisfied considerably in order to achieve the organizational objectives. It is evident from the researcher's study that those employees that are satisfied and efficient highly concern towards the organizational success rather than looking at the organizational size or other perspective.

Performance based compensation is usually being offered to the employees and it includes two types such as: evaluation is being done to analyze the employee's performance and provide them 
compensation or compensation is being offered on the basis of organizational profitability (Ogbonnaya et al, 2017). Previous studies suggested that there is a significant association among the compensation and employee attitude which increases the positivity and productivity (Green, 2004). It is evident from the study that those type of compensation that are based upon the performance based it increases the motivation level among the individual and productivity increases considerably (Ogbonnaya et al, 2017).

Compensation includes the financial aspect and non financial aspect as well; such as incentives, bonus, commission, profit related incentives and others are considered as the financial aspects while on the other hand; non financial aspects are promotions, authority delegation, insurance, shares and others are considered as the non monetary benefits for the employees (Casio, 2013). In order to motivate employees compensation is the important tool that are being used by the organizations to increase efficiency and productivity; that also increases the effectiveness and profitability of the organization (Casio, 2013). Internationally compensation system is being included the salary according to the individual abilities, skills, capabilities, performance, living allowances, inflation covered, offering bonus twice in the calendar year, along with this employees performance is also linked with it to get increased share of the pay and for the future prospective pension and provident fund is being the part of this plan (Conrad, 2009).

Training is considered as the systematic process that increases the efficiency and skills of the employees in order to improve the performance that contributes the overall performance of the organization. Training and development of the employees is planned when the employees are hired or recruited in order to equipped them adequately to meet the challenges at the workplace and external environment as well (Al Saleem, 2010). Training is the activity that brings change in the attitude and behavior of the individual to increase the capabilities, knowledge and skills to facilitate efficiency and effective learning; that enable the employees to meet the organizational objectives and working requirement in the organization (Bosninih and Al Farsi, 2003). Training is to focus upon the development in the attitude and individual efficiency. There are number of training provided by the organizations to the employees that are: on job training, orientation, safety, promotional, refresher, remedial and others increases the skills and capability of the employees (Choudhary and Lamba, 2013).

Training of the employees increases their confidence and skills that meet the future work requirement considerably, training is also considered as the professional education which is being provided to aim that employees will contribute in the attainment of strategic goals or objectives (Zuelv, 2003). The study suggested that there is a positive association among the variable of training with the job satisfaction. The job satisfaction of the employees are based upon the content of the training and facilitating feature is that it should be according to the increasing the knowledge and expertise of the individual rather than providing those information or skills that are already equipped and embedded in the individual (Joudeh, 2010). The features of the training involve the time input to get training, training methods, subject of the training and trainees are given specific time to learn the knowledge and meet the objectives of the training that they should be having improved skills and capabilities that can increases their performance and efficiency.

Performance appraisal is a measure that inculcates about the overall performance of the individual throughout the years and assessed the designated objectives are being achieved within the specific 
time period. There are different scales, rating and test used to assess the performance of the individual (Murphy and Cleveland, 1995). The most important feature for the performance appraisal is that rater should not be biased and having enough knowledge to rate adequately. In the last three decades performance appraisal is having high concern for the human resource professional. The first industrial rating system back in 1800 was developed by Robert Owen at the Cotton Mills in Scotland (Heilbroner, 2011).

Managers of the organization are required to perform their duties without biasness to ensure that deserving employee should be rewarded adequately; it is suggested in the study that there is a strong association with the trust in the management and employee perception that they are going to be treated fairly which increases the job satisfaction among the employees (Farndale and Kelliher, 2013). It is important that individual performance and team's performance enable to determine the overall organizational performance (Bratton and Gold, 2012). It is important that organization should focus upon the communication in the organization to get the performance appraisal system improved (Towell, 2012).

The purpose of the study is to analyze the effects of human resource management on employee satisfaction. The previous studies focused upon different variables and in this study researcher has selected four independent variables such as planning and recruitment, training, compensation and performance appraisal while the dependant variable is employee satisfaction. The selected variables are from the human resource management practices and largely used in the daily routine operations of the corporate sector. It will help the researcher to assess these variables that can provide employee satisfaction at their jobs and will help to identify those factors that are the main cause that disrupt the employee satisfaction.

\section{Conceptual Framework}

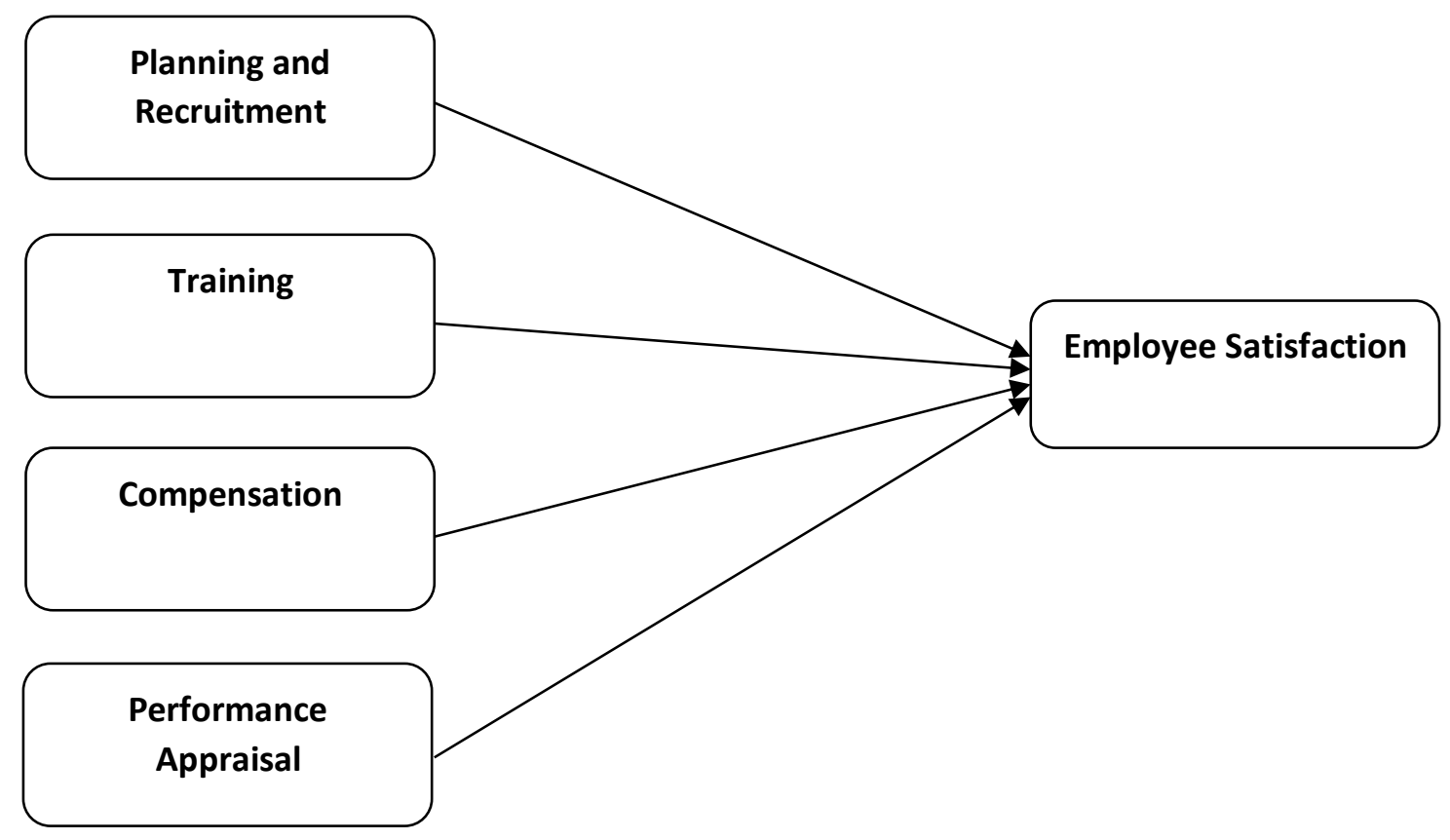




\section{Methodology}

The study seeks to investigate the effect of human resource management practices on employees' satisfaction. The study in quantitative in nature as it seeks to empirically test the relationships using a close ended questionnaire.

\section{Questionnaire Design}

To collect the data from the respondents a questionnaire was used. The questionnaire contained two parts. Part A comprised of the questions regarding the demographic information of the respondents while part $B$ asked the questions regarding the variables included in the research framework. All questions were designed using five-point likert scale. All the construct used in the research framework was measured using multi-items.

\section{Sample size and Technique}

A random sampling technique was used to draw the sample. A sample of 380 respondents was used to analyze the data. Initially the questionnaire was distributed among 500 individuals out of them 395 questionnaires were returned. However 15 of them were left partially or fully unfilled. Hence the remaining 380 questionnaires were found to be useful.

\section{Data Analysis}

The data was initially put in the software using a predefined codebook. The data was first cleaned and preliminary analysis were done. The preliminary analysis include missing values treatment, normality and outliers etc. The main analysis then included demographic analysis, descriptive statistics, reliability, correlation and regression. SPSS 22 was employed to examine the data. 


\section{Results and Findings}

The results of data analysis are presented in the following section.

\section{Demographic Analysis}

Gender

\begin{tabular}{|ll|l|l|l|l|}
\hline & & Frequency & Percent & Valid Percent & Cumulative Percent \\
\hline Gender & Male & 271 & 71.3 & 71.3 & 71.3 \\
& Female & 109 & 28.7 & 28.7 & 100.0 \\
& Total & 380 & 100.0 & 100.0 & \\
\hline Age & $20-25$ & 130 & 34.2 & 34.2 & 34.2 \\
& $26-35$ & 193 & 50.8 & 50.8 & 85.0 \\
36-45 & 44 & 11.6 & 11.6 & 96.6 \\
Above 45 & 13 & 3.4 & 3.4 & 100.0 \\
Total & 380 & 100.0 & 100.0 & .5 \\
\hline Education & Secondary & 2 & .5 & .5 & 20.3 \\
Diploma & 75 & 19.7 & 19.7 & 87.9 \\
Bachelors & 257 & 67.6 & 67.6 & 98.7 \\
Masters & 41 & 10.8 & 10.8 & 100.0 \\
PhD. & 5 & 1.3 & 1.3 & \\
Total & 380 & 100.0 & 100.0 & \\
\hline
\end{tabular}

The demography of the respondents is presented in the above table. The table shows that out of total 380 respondents 271 were male and 109 were females. The age of the respondents was between 26 and 25 for around $50 \%$ of the respondents while 34\% were aged between 20 and 25 . 11\% were 3645 years old while remaining $3 \%$ were above the age of 45 . As far as the education of the respondents is concerned only 2 were having the secondary education, 75 were holding diploma, 257 were bachelors and 41 were masters. However only 5 respondents were holding a PhD degree.

\section{Descriptive Statistics}

\begin{tabular}{|l|l|l|l|l|l|}
\hline & $\mathrm{N}$ & Minimum & Maximum & Mean & Std. Deviation \\
\hline EMPL_SAT & 380 & 1.00 & 5.00 & 3.2618 & 1.06695 \\
\hline PLAN_REC & 380 & 1.00 & 5.00 & 3.3263 & 1.11631 \\
\hline TRAINING & 380 & 1.00 & 5.00 & 3.1382 & 1.09116 \\
\hline COMPENSATION & 380 & 1.00 & 5.00 & 3.0877 & .83989 \\
\hline PERFORM_APP & 380 & 1.00 & 5.00 & 2.9395 & .93044 \\
\hline
\end{tabular}

The above table shows the descriptive statistics of the variables included in the research framework. The minimum and maximum value of the all the variables were 1 and 5 respectively. The mean values ranged between 2.93 to 3.32 while the standard deviation ranged between 0.83 and 1.11. Moreover the total number of observation of 380 showed the sample size was 380 . 


\section{Reliability}

The reliability of the constructs in shown in the table below.

\begin{tabular}{|l|l|l|}
\hline Constructs & No of Items & Cronbach's Alpha \\
\hline Employee Satisfaction & 04 & 0.840 \\
\hline Planning and Recruitment & 04 & 0.867 \\
\hline Training & 04 & 0.843 \\
\hline Compensation & 04 & 0.830 \\
\hline Performance Appraisal & 04 & 0.785 \\
\hline
\end{tabular}

The above table of the reliability shows the values of Cronbach's Alpha for each of the constructs. The values of alpha were found to be between 0.785 and 0.867 . Hence all the values were found to be above the threshold value of 0.7 . Which means the requirement for the construct reliability was met.

\section{Correlation Analysis}

\section{Correlations}

\begin{tabular}{|c|c|c|c|c|c|c|}
\hline & & $\begin{array}{l}\text { EMPL_SA } \\
T\end{array}$ & PLAN_REC & TRAINING & $\begin{array}{l}\text { COMPENSATIO } \\
\mathrm{N}\end{array}$ & $\begin{array}{l}\text { PERFORM_AP } \\
\text { P }\end{array}$ \\
\hline EMPL_SAT & $\begin{array}{l}\text { Pearson } \\
\text { Correlation } \\
\text { Sig. (2-tailed) } \\
\mathrm{N}\end{array}$ & $\begin{array}{l}1 \\
380 \\
\end{array}$ & & & & \\
\hline PLAN_REC & $\begin{array}{l}\text { Pearson } \\
\text { Correlation } \\
\text { Sig. (2-tailed) } \\
\mathrm{N}\end{array}$ & $\begin{array}{l}.316^{* *} \\
.000 \\
380\end{array}$ & $\begin{array}{l}1 \\
380\end{array}$ & & & \\
\hline TRAINING & $\begin{array}{l}\text { Pearson } \\
\text { Correlation } \\
\text { Sig. (2-tailed) } \\
\mathrm{N}\end{array}$ & $\begin{array}{l}.266^{* *} \\
.000 \\
380 \\
\end{array}$ & $\begin{array}{l}.276^{* *} \\
.000 \\
380 \\
\end{array}$ & $\begin{array}{l}1 \\
380 \\
\end{array}$ & & \\
\hline $\begin{array}{l}\text { COMPENSATIO } \\
\mathrm{N}\end{array}$ & $\begin{array}{l}\text { Pearson } \\
\text { Correlation } \\
\text { Sig. (2-tailed) } \\
\mathrm{N}\end{array}$ & $\begin{array}{l}.241^{* *} \\
.000 \\
379\end{array}$ & $\begin{array}{l}.025 \\
.628 \\
379\end{array}$ & $\begin{array}{l}-.028 \\
.584 \\
379\end{array}$ & $\begin{array}{l}1 \\
379 \\
\end{array}$ & \\
\hline PERFORM_APP & $\begin{array}{l}\text { Pearson } \\
\text { Correlation } \\
\text { Sig. (2-tailed) } \\
\mathrm{N}\end{array}$ & $\begin{array}{l}.167^{* *} \\
.001 \\
380\end{array}$ & $\begin{array}{l}-.251^{* *} \\
.000 \\
380\end{array}$ & $\begin{array}{l}-.065 \\
.208 \\
380\end{array}$ & $\begin{array}{l}.051 \\
.324 \\
379\end{array}$ & $\begin{array}{l}1 \\
380\end{array}$ \\
\hline
\end{tabular}

\footnotetext{
**. Correlation is significant at the 0.01 level (2-tailed).
} 
The above table of correlation shows that all independent variables (Planning and Recruitment, Training, Compensation and Performance Appraisal) were significantly correlated with the dependent variable (Employee Satisfaction) as the p-values for all the correlations were below 0.05 . Moreover the correlation among the independent variables ranged from 0.025 to 0.276 which shows the low values of correlation. The correlation value of 0.9 and above between independent variables shows the high probability of multicollinearity between the two independent variables. However this issue was not found in the current data.

\section{Regression}

To test the hypotheses of the study regression analysis was performed the result of the regression analysis is shown in the table below.

\section{Coefficients $^{\mathrm{a}}$}

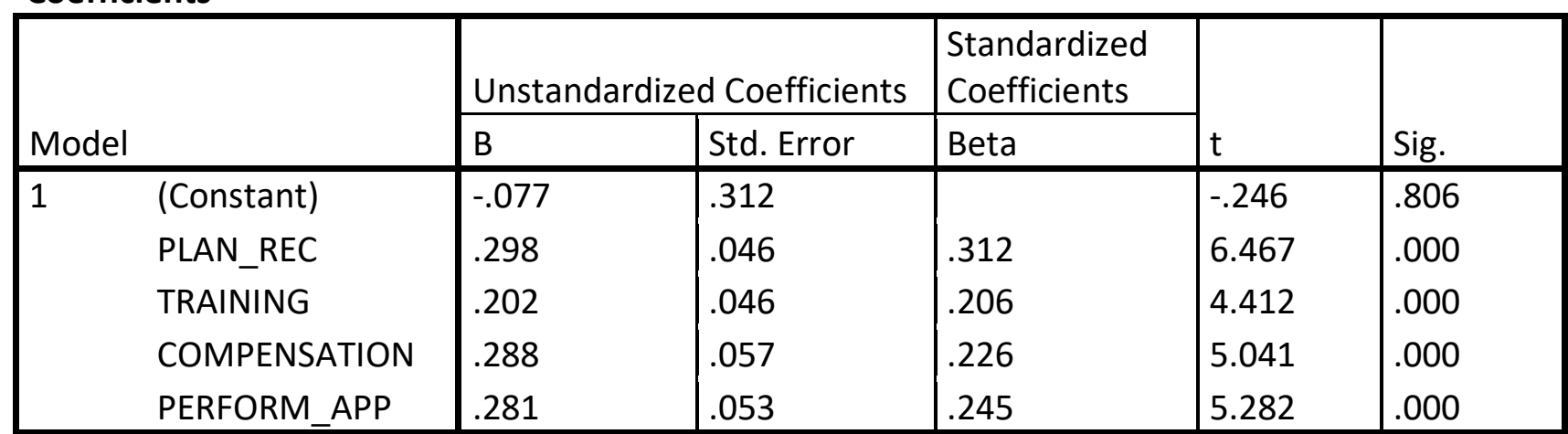

a. Dependent Variable: EMPL_SAT

The above table of the regression analysis shows that planning and recruitment, training, compensation and performance appraisal have significant impact on employee satisfaction as the $p$ values were below 0.05 . Moreover all the beta coefficients were having a positive sign which shows that all relationships were positive. The summary of the hypotheses is presented in the table below.

\section{Summary of Hypotheses}

\begin{tabular}{|l|l|l|}
\hline Hypotheses & P-values & Results \\
\hline $\begin{array}{l}\text { There is a positive impact of planning and recruitment on employee } \\
\text { satisfaction. }\end{array}$ & 0.000 & Supported \\
\hline There is a positive impact of training on employee satisfaction. & 0.000 & Supported \\
\hline $\begin{array}{l}\text { There is a positive impact of compensation on employee } \\
\text { satisfaction. }\end{array}$ & 0.000 & Supported \\
\hline $\begin{array}{l}\text { There is a positive impact of performance appraisal on employee } \\
\text { satisfaction. }\end{array}$ & 0.000 & Supported \\
\hline
\end{tabular}

The above table shows that all the hypotheses were found to be supported hence it can be said that planning and recruitment, training, compensation and performance appraisal have positive and significant impact on employee's satisfaction. 


\section{Discussion and Conclusion}

The study was aimed to find out the impact of planning and recruitment, training, compensation and performance appraisal on employees satisfaction. The results showed the significant impact of all the above variables. The human resource strategic planning is associated with the recruitment, training and retaining the employees of the organization (Al Saleem, 2010). Planning of human resource department is associated with the strategic planning of the organization to recruit right person for the right job, provide training and evaluate performance of the individuals in order to motivate them and urge them to produce quality results for the organization. It is required to collect the concrete and purposeful information that enable the organization to take effective strategic decision which enable the organizational success (Joudeh, 2010). Hence the results are aligned with the above said literature. In order to motivate employees compensation is the important tool that are being used by the organizations to increase efficiency and productivity; that also increases the effectiveness and profitability of the organization (Casio, 2013). Training of the employees increases their confidence and skills that meet the future work requirement considerably, training is also considered as the professional education which is being provided to aim that employees will contribute in the attainment of strategic goals or objectives (Zuelv, 2003). The study suggested that there is a positive association among the variable of training with the job satisfaction. The job satisfaction of the employees are based upon the content of the training and facilitating feature is that it should be according to the increasing the knowledge and expertise of the individual rather than providing those information or skills that are already equipped and embedded in the individual (Joudeh, 2010). It is important that individual performance and team's performance enable to determine the overall organizational performance (Bratton and Gold, 2012). It is important that organization should focus upon the communication in the organization to get the performance appraisal system improved (Towell, 2012). The above literature supports the results of the study and hence it can be said that the study provides the evidence that planning, training, compensation and performance appraisal significantly effects the employee satisfaction.

\section{Recommendations}

As per the findings discussed above planning and recruitment, training, compensation and performance appraisal have positive and significant impact on employee's satisfaction. This key findings leads to the idea that it is essential for the organization to have better HR policies to have satisfied employees. It is recommended to the Iraqi organizations to articulate better and strong HR policies which are in the favor of employees as the workforce of any organization is the back bone of that organization hence having a better workforce leads to the better organizational performance which ultimately leads to the growth and development of the organization.

\section{Limitation and Future Research}

The above study is limited to the four function of Human resource management. In future research more functions can be examined. Moreover the study only include the close ended questionnaire as data collection tool hence resulting in a quantitative study. Future researches can be done employing mixed method research to develop the in-depth understanding of the phenomena. Moreover a comparative study can be performed to understand the relationship in different cultural contexts. 


\section{References}

Al Salem, M. (2010). Human Resources Management Integrated Strategic Approach. (Unpublished doctoral thesis).University Library, Sharjah UAE.

Bhagul, D. (2014). Glimpses Of Hrd Practices In Pharmaceuticals Companies In Pune. Solapur, India: Laxmi Book Publication.

Bosninih, S., \& Al-Farsi A. (2003). Human Resources: relevance, organization, responsibilities and functions, Tripoli, Libya: graduate Academy.

Bratton, J., \& Gold, J. (2012). Human Resource Management: Theory and Practice. London, United Kingdom: Palgrave Macmillan.

Casio, W. F. (2013). Managing Human Resources: Productivity, Quality of Work Life, Profits. New York,USA: McGraw-Hill Irwin.

Choudhary, N., \& Lamba, S. (2013). Impact of HRM Practices On Organizational Commitment Of Employees. International Journal of Advancements in Research \& Technology, 2(4), 407-422.

Conrad, H. (2009). From Seniority To Performance Principle: The Evolution Of Pay Practices In Japanese Firms Since 1990's. Social Science Japan Journal, 13(1), 115-135.

Curran, B., \& Walsworth, S. (2014). Can you Pay Employees to Innovate? Evidence from the Canadian Private Sector. Human Resource Management Journal, 24(3), 290-306.

Darwish, T. (2013). 10 Strategic HRM and Performance: Theory and Practice. Newcastle, United Kingdom: Cambridge Scholars Publishing.

Denisi, A., \& Griffin R. (2005). Human Resource Management, New York, USA: Houghton Mifflin Company.

Dessler, G. (2013). Human Resource Management. New Jersey, USA: Pearson Education.

Farndale, E., \& Kelliher, C. (2013). Implementing Performance Appraisal: Exploring the Employee Experience. Human Resource Management, 52(6), 879-897.

Fening, F., \& Amaria, P. (2011). Impact of human resource management practices on small firm performance in a country in recession. American Journal of Business Research, 4(1), 23-54.

Green, C., \& Heywood, J. (2008). Does performance pay increase job satisfaction? Economica from London School of Economics and Political Science, 75(300), 710-728.

Haquec, R., Islam, S., Chowdhury, S., Akhter, R., \& Rahman, M. (2013). HRM Practices and its Impact on Employee Satisfaction: A Case of Pharmaceutical Companies in Bangladesh. International Journal of Research in Business and Social Science, 2(3), 62-67.

Heilbroner, L. R. (2011). The Worldly Philosophers: The Lives, Times And Ideas Of The Great Economic Thinkers. New York, USA: Touchstone.

Heneman, H, \& Milanowski, A., (2007). Assessing Human Resource Alignment: The Foundation for Building Total Teacher Quality Improvement. Madison: University of Wisconsin, Wisconsin Center for Education Research, Consortium for Policy Research in Education.

Heywood, J., \& Wei, X. (2006). Performance pay and job satisfaction. Journal of Industrial Relations, 48(4), 523-540.

Joudeh, M. (2010). Human Resources Management. , Amman, Jordan: Weal Publishing.

Moriones, B. A., \& Larraza-Kintana, M. (2009). Profit-sharing plans and affective commitment: does the context matter?. Human Resource Management, 48(2), 207-226. 
Murphy, K., \& Cleveland, J. (1995). Understanding Performance Appraisal: Social, Organizational, and Goal-Based Perspectives. London, United Kingdom: SAGE Publications.

Ogbonnaya, C., Daniels, K., \& Nielsen, K. (2017). Does contingent pay encourage positive employee attitudes and intensify work?. Human Resource Management Journal, 27(1) 94- 112.

Pendleton, A., Whitfield, K. \& Bryson, A. (2009). The changing use of contingent pay at the modern British workplace', in W. Brown, A. Bryson, J. Forth and K. Whitfield (eds), The Evolution of the Modern Workplace, Cambridge: Cambridge University Press.

Shadare, O. A., \& Hammed, T. A. (2009). Influence of work motivation, leadership effectiveness and time management on employees' performance in some selected industries in Ibadan, Oyo State, Nigeria. European Journal of Economics, Finance and Administrative Sciences, 16, 7-17.

Shaukat, H., Ashraf, N., \& Ghafoor, S. (2015). Impact of Human Resource Management Practices on Employees Performance. Middle-East Journal of Scientific Research, 23(2), 329-338.

Towell, M. (2012). How can coaching improve the effectiveness of Performance Management Conversations? Doctorate of Mentoring and Coaching, Oxford Brookes University.

Umphress, E. E., K, Smith-Crowe., AP, B., J, D., \& M. B. Watkins. (2007). When Birds of a Feather Flock Together and When They Do Not: Status Composition, Social Dominance Orientation, and Organizational Attractiveness. Journal of Applied Psychology, 92(2), 396-409.

Watson, T. J. (2010). Critical social science, pragmatism and the realities of HRM. The International Journal of Human Resource Management, 21(6), 915-31.

Wood, S.J., \& Wall, T.D. (2002). Human resource management and business performance. In P.B.Warr (Ed.), Psychology at work. Harmonsworth: Penguin,

Zuelv, M. (2003). People management. Amman, Jordan: Dar Al-Safa for publication and distribution. 